Proc. Estonian Acad. Sci. Eng., 2005, 11, 3, 215-225

\title{
Behaviour of wind speed fronts
}

\author{
Teolan Tomson and Maire Hansen \\ Department of Materials Science, Tallinn University of Technology, Ehitajate tee 5, 19086 Tallinn, \\ Estonia; teolan@anet.ee \\ Received 6 June 2003, in revised form 5 February 2004

\begin{abstract}
This article describes methods for determining wind speed increments in relation to wind fronts and their dependence on the height of measurement, average wind speed and wind direction. Wind directions and speeds, which can produce the most powerful wind fronts, significant for the performance of the Estonian power system, are analysed. The impact of wind speed fronts to the behaviour of a grid of wind turbine generators is assessed.
\end{abstract}

Key words: wind speed front, frequency distribution function, power system.

\section{INTRODUCTION}

This study can be regarded as a preliminary step in the analysis of wind power increments, which have practical relevance in the assessment of cooperation conditions for wind turbine generators (WTGs) in the Estonian power system.

The running reserve of a power system has to ensure that the instant generated and consumed capacities maintain balance. WTGs in the grid perform like negative loads and their instability adds up to the instability of the conventional load $\left.{ }^{1}\right]$. In the normal stabilized wind conditions, wind speed and wind capacity are stationary random processes, but in the transient conditions, positive and negative wind power fronts (increments) appear. Wind power increments are caused by wind speed increments, which have to be studied first, particularly due to insufficient experience in wind energy maintenance $\left[{ }^{2}\right]$.

In dispatcher-services of power systems and in the literature $\left[{ }^{3}\right]$, power increments are defined as the difference between the average values of capacities over an one-hour interval. We assess capacities $P^{*}$ in relative units and the conventional (wind) power increment, respectively, as

$$
\Delta P^{*}=P^{*}(h+1)-P^{*}(h),
$$


where $h$ is the time instant on the discrete time scale with an one-hour step. A similar approach allows us to define the wind speed increment as

$$
\Delta u=u(h+1)-u(h)
$$

where $u$ is the average ${ }^{1}$ wind speed $\left(\mathrm{m} \mathrm{s}^{-1}\right)$. An example of a crucial wind front is presented in Fig. 1, recorded at Cape Ristna, Harjumaa County, (also "Ristinina" $\left[{ }^{4}\right]$ ) on 1 November 2001 at the height of $32 \mathrm{~m}$.

Usually instances of wind fronts do not coincide in geographically shifted sites, which is beneficial for power grids. It is shown in Fig. 2, where the positive wind speed increments in the mainland (Uulurand (ULR), Pärnu meteorological station (PRN) and Pärnu Airport (PLJ)) have approximately a two-hour time lag against the island of Kihnu (KHN). The distance between KHN and mainland is approximately $40 \mathrm{~km}$, and the distance between PRN and PLJ is less than $4 \mathrm{~km}$. Thus, sparse measurements with a three-hour interval in the PRN site do not allow us to describe the wind speed increment accurately. Because of this inaccuracy we have to deal with the influence of data recording and processing technology on the result of the assessed wind speed increment.

Irregular transient processes can be presented and evaluated by their frequency distribution function $F(\Delta u)$, which shows the probability of wind speed increments as a function of their value.

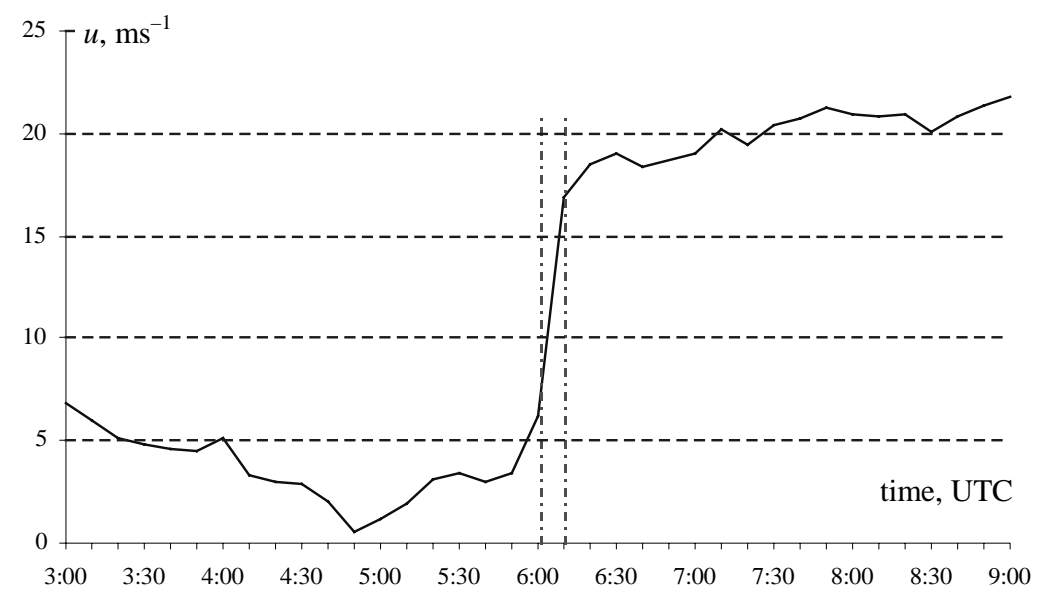

Fig. 1. Crucial front of wind speed at Cape Ristna on 1 November 2001 at the height of $32 \mathrm{~m}$.

\footnotetext{
${ }^{1}$ Average over one hour or over 10 minutes, depending on measurement conditions.
} 


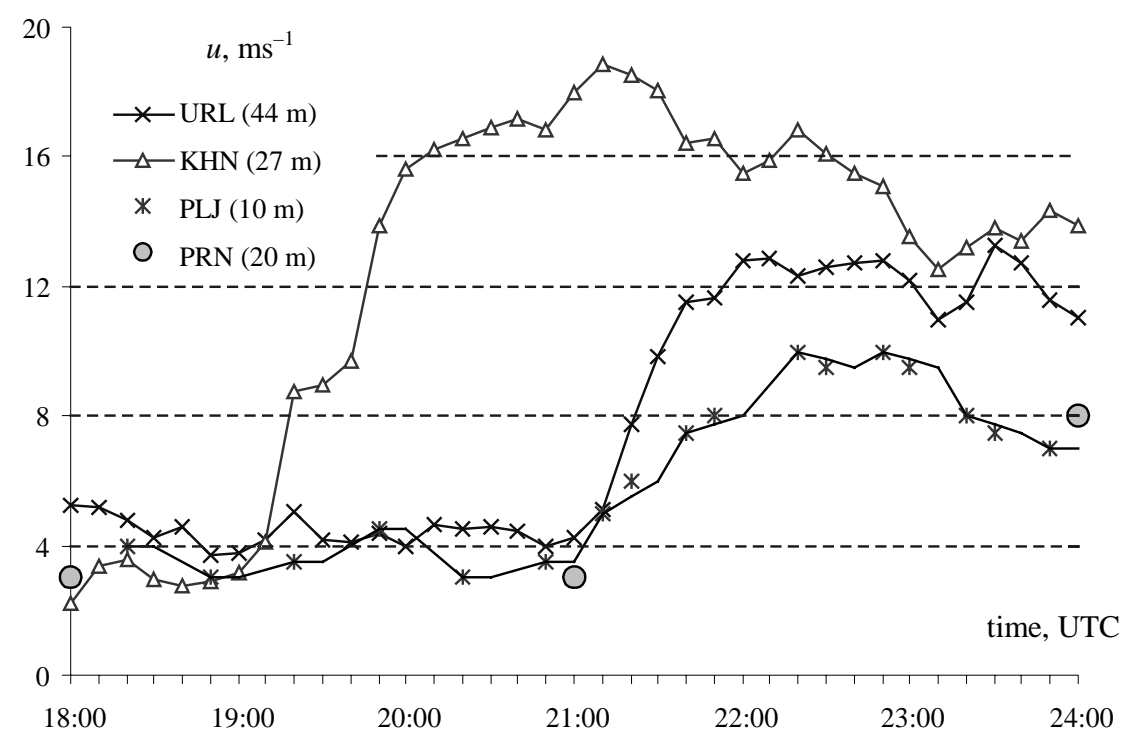

Fig. 2. Wind speed fronts at the ULR, KHN, PLJ and PRN sites on 5 November 2000; the heights of measurement are shown in parentheses.

\section{DATA SERIES USED}

The data series used in the study are shown in Table 1. For each coordinate, height of the anemometer and sampling interval are given. The last column shows the recording period; in case different data are compared, their recorded data are synchronized. It means that different recording periods overlap.

Table 1. Data series used

\begin{tabular}{|c|c|c|c|c|c|}
\hline Site & $\begin{array}{l}\text { Abbrevia- } \\
\text { tion }\end{array}$ & Coordinates & $\begin{array}{l}\text { Height of the } \\
\text { anemometer, } \\
\text { m }\end{array}$ & $\begin{array}{c}\text { Sampling } \\
\text { interval, } \\
\text { min }\end{array}$ & $\begin{array}{l}\text { Recording } \\
\text { period }\end{array}$ \\
\hline Harilaid & HRL & $\begin{array}{l}58^{\circ} 26^{\prime} \mathrm{N}, \\
23^{\circ} 3^{\prime} \mathrm{E}\end{array}$ & $20,35,50$ & 10 & 1997-1998 \\
\hline Kootsaare & KTS & $\begin{array}{l}59^{\circ} 58^{\prime} \mathrm{N}, \\
22^{\circ} 28^{\prime} \mathrm{E}\end{array}$ & 10,18 & 10 & III-VIII 1998 \\
\hline Ristna & RSN & $\begin{array}{l}59^{\circ} 17^{\prime} \mathrm{N}, \\
23^{\circ} 44^{\prime} \mathrm{E}\end{array}$ & 32 & 10 & 2000-2002 \\
\hline Kihnu & KHN & $\begin{array}{l}58^{\circ} 6^{\prime} \mathrm{N} \\
23^{\circ} 58^{\prime} \mathrm{E}\end{array}$ & 10,27 & 10 & 1999-2000 \\
\hline $\begin{array}{l}\text { Pärnu meteor. } \\
\text { station }\end{array}$ & PRN & $\begin{array}{l}58^{\circ} 22^{\prime} \mathrm{N}, \\
24^{\circ} 30^{\prime} \mathrm{E}\end{array}$ & 20 & 180 & 1999-2001 \\
\hline Pärnu Airport & PLJ & $\begin{array}{l}58^{\circ} 23^{\prime} \mathrm{N} \\
24^{\circ} 29^{\prime} \mathrm{E}\end{array}$ & 10 & 10 & 01 XI 2001 \\
\hline Uulurand & ULR & $\begin{array}{l}58^{\circ} 17^{\prime} \mathrm{N} \\
24^{\circ} 35^{\prime} \mathrm{E}\end{array}$ & 26,44 & 10 & $2000-2001$ \\
\hline
\end{tabular}


Table 1. Continued

\begin{tabular}{|c|c|c|c|c|c|}
\hline Site & $\begin{array}{l}\text { Abbrevia- } \\
\text { tion }\end{array}$ & Coordinates & $\begin{array}{l}\text { Height of the } \\
\text { anemometer, } \\
\text { m }\end{array}$ & $\begin{array}{l}\text { Sampling } \\
\text { interval, } \\
\text { min }\end{array}$ & $\begin{array}{l}\text { Recording } \\
\text { period }\end{array}$ \\
\hline Prangli & PRG & $\begin{array}{l}59^{\circ} 39^{\prime} \mathrm{N} \\
24^{\circ} 58^{\prime} \mathrm{E}\end{array}$ & 30 & 60 & 1993-1994 \\
\hline Avaste & AVA & $\begin{array}{l}58^{\circ} 37^{\prime} \mathrm{N}, \\
24^{\circ} 5^{\prime} \mathrm{E}\end{array}$ & 10,27 & 10 & 2002-2003 \\
\hline Virtsu & VRT & $\begin{array}{l}58^{\circ} 35^{\prime} \mathrm{N} \\
23^{\circ} 31^{\prime} \mathrm{E}\end{array}$ & 63 & 10 & XI 2002-III 2003 \\
\hline Näsudden & NSD & $\begin{array}{l}57^{\circ} 10^{\prime} \mathrm{N} \\
18^{\circ} 12^{\prime} \mathrm{E}\end{array}$ & $\begin{array}{c}10,32,53,75 \\
97,118,145\end{array}$ & 60 & 1987-1989 \\
\hline
\end{tabular}

\section{POSITIVE AND NEGATIVE INCREMENTS OF WIND SPEED}

Positive and negative increments of the wind power, caused by positive and negative increments of the wind speed, are equally harmful for power balance in the grid. An analysis of the recorded data in Fig. 3 shows equal frequency distribution functions, $F(\Delta u>0)=F(\Delta u<0)$. Studies of wind power increments $\left[{ }^{3,5,6}\right]$ confirm this result. Therefore we shall study the absolute values of wind speed increments

$$
\Delta u=|u(h+1)-u(h)| .
$$

Figure 4 shows that the frequency distribution function $\Phi(\Delta u)$ depends on the average value of the wind speed increment, but the average value of the wind speed increment is independent of the average value of wind speed $\mu \Delta u$. Scattered

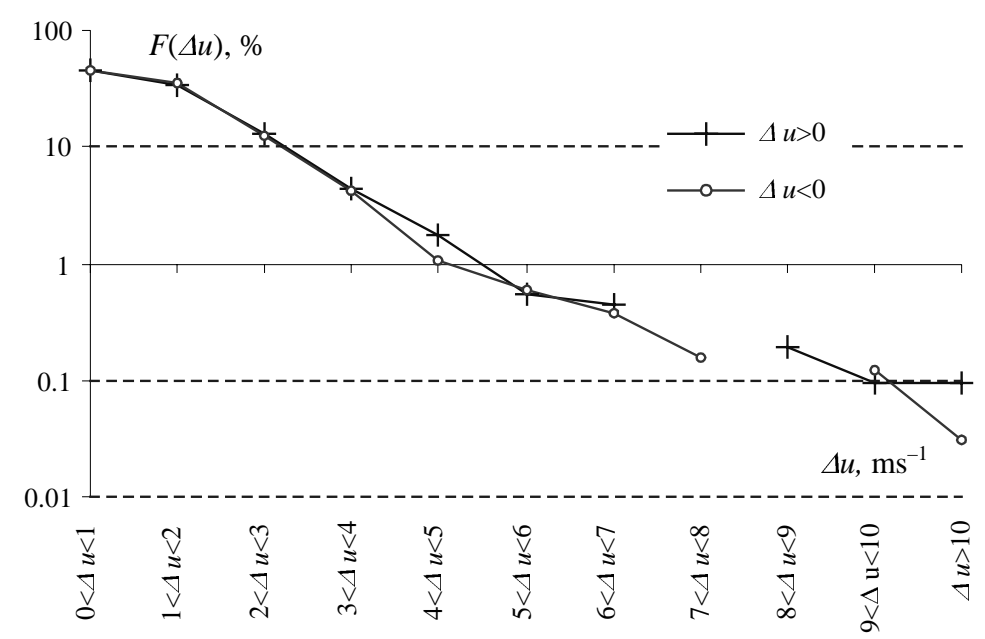

Fig. 3. Frequencies of positive and negative wind speed increments at HRL, measured at $50 \mathrm{~m}$. 




Fig. 4. Dependence of the frequency $\Phi(\Delta u)$ of the wind speed increment on the value of increment and average value of wind speed increment $\mu \Delta u(u)$ on the average value of wind speed at KHN, at the heights of 10 and $27 \mathrm{~m}$.

values of wind speed increments at the high level of wind speed $\left(u>12 \mathrm{~m} \mathrm{~s}^{-1}\right)$ is a result of the low number of measurements. Thus the frequency arrangement function $\Phi(\Delta u)$ depends on the anemometer elevation and $\Phi(\Delta u)$ with the maximum at higher wind speed $\left(7.5 \mathrm{~m} \mathrm{~s}^{-1}\right.$ at $27 \mathrm{~m} \mathrm{vs} 4.5 \mathrm{~m} \mathrm{~s}^{-1}$ at $\left.10 \mathrm{~m}\right)$ has a lower value.

\section{WIND SPEED INCREMENTS AS A FUNCTION OF ELEVATION}

The average value of the wind speed is a well-known non-linear function of the measurement height $\left[{ }^{7}\right]$. Wind speed increments also depend on the height. Our studies were based on the data from HRL, KTS and NSD. HRL, a low islet without trees, is in the centre of the Hari Sound, where the coastline is within a distance of several kilometres and surrounding sea has low value of the roughness. KTS, located immediately on the waterline, is open to the sea in the sector W-NE, surrounded with low grassland. The frequency distribution functions of wind speed increments at KTS (at $18 \mathrm{~m}$ ) and HRL (at $20 \mathrm{~m}$ ) differ, while their elevations are practically the same (Fig. 5). The reason lies in the differences in roughness of the landscape away from the measuring sites. No differences exist between distribution functions at KTS for heights 10 and $18 \mathrm{~m}$. Frequency distribution functions at HRL also practically coincide for the heights 20, 35 and $50 \mathrm{~m}$. Figure 6 shows the same phenomenon for NSD (southern tip of the Gotland Island); the frequency distribution functions for the heights from 32 to $145 \mathrm{~m}$ practically coincide. The frequency distribution function at the height of 
$10 \mathrm{~m}$ differs significantly. The landscape around the Näsudden Land Tower is variable, according to the map. It can be suggested that the distribution function for the wind speed increments depending on the height is close to the step function: it is constant for the heights of $10-20 \mathrm{~m}$ and over $30 \mathrm{~m}$ (on the sea over $20 \mathrm{~m}$ ). The frequency of any wind increment is twice lower for a lower elevation range, as can be seen in Figs. 5 and 6.

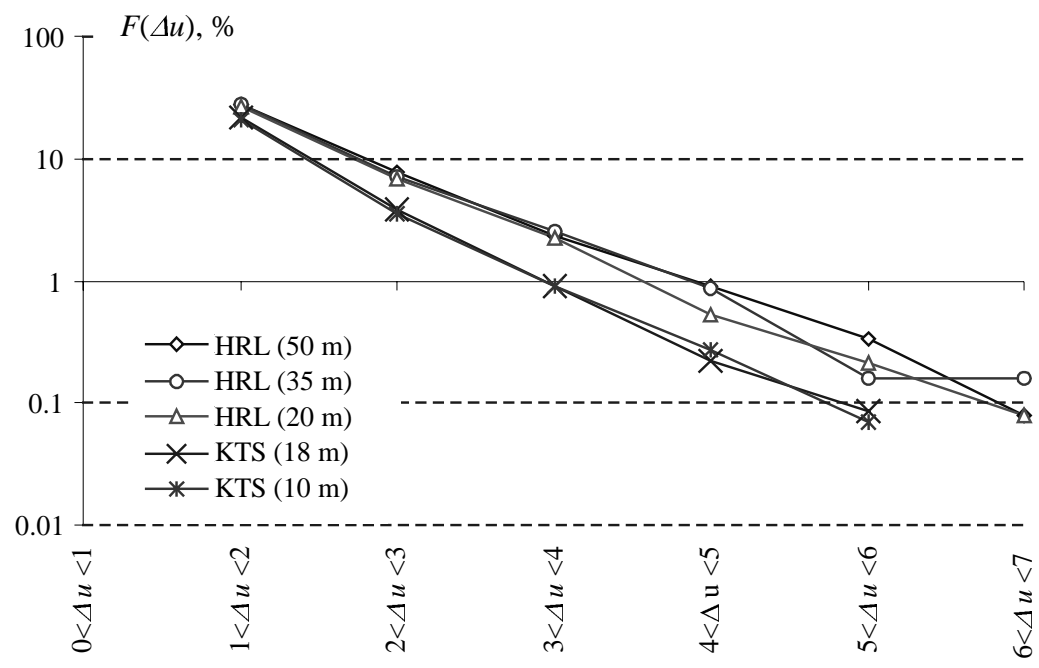

Fig. 5. Frequency distribution functions of wind speed increments, depending on the height at HRL and KTS sites.



Fig. 6. Frequency distribution functions of the wind speed increments for different heights at NSD site. 


\section{WIND SPEED INCREMENTS AS A FUNCTION OF AZIMUTH}

Figures 7-9 show conventional wind roses for KHN, HRL and PRG sites and the corresponding diagrams for small $\left(\Delta u \approx 2 \mathrm{~m} \mathrm{~s}^{-1}\right)$ and large $\left(\Delta u \approx 4 \mathrm{~m} \mathrm{~s}^{-1}\right)$ wind speed increments. The diagrams of small wind speed increments always correspond to conventional wind roses, but the diagrams for large wind speed increments reach a maximum over the NW sector. Thus it can be concluded that problems in Estonian grid may be caused by the north-western winds if the share of WTGs increases significantly.

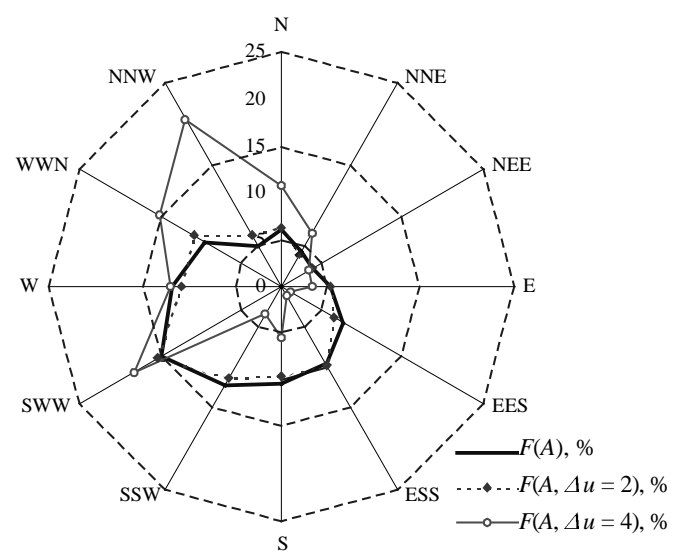

Fig. 7. Wind speed and increment roses at KHN.

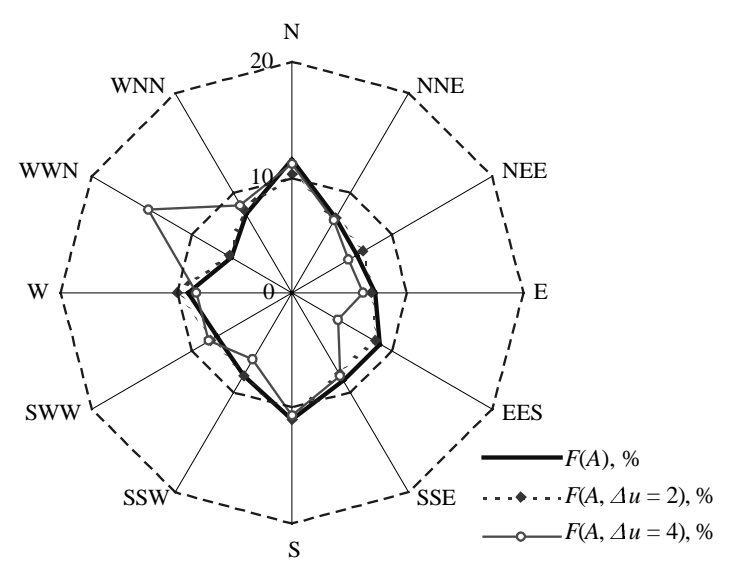

Fig. 8. Wind speed and increment roses at HRL. 


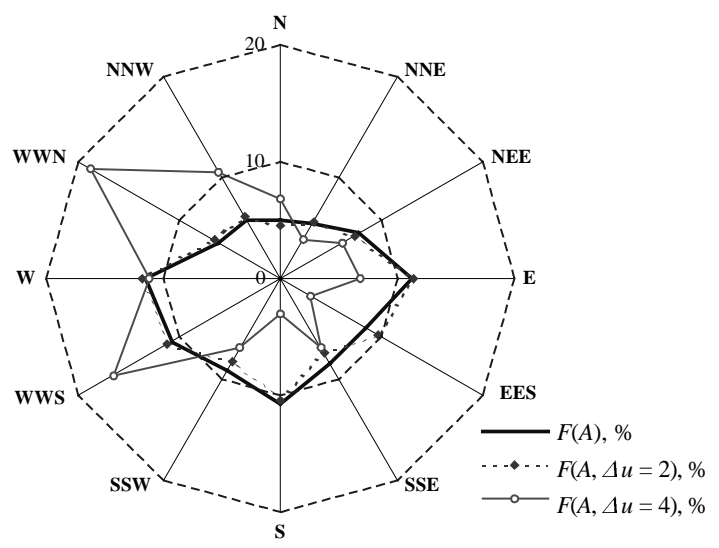

Fig. 9. Wind speed and increment roses at PRG.

\section{WIND SPEED INCREMENTS AS A FUNCTION OF DATA RECORDING}

According to the definition, the wind speed increment is a difference of wind speeds during an one-hour interval. Thus its value depends on the choice of the interval. While the data are recorded with a one-hour interval (NSD, PRG), the simple wind speed increment $\Delta u$ can be calculated in a simple way from Eq. (3). While the data are recorded with a 10-minute interval (most of the recorded data in Table 1), within a discrete one-hour interval greater wind speed increments can be found, which cannot be calculated using an hourly time scale (Fig. 10).

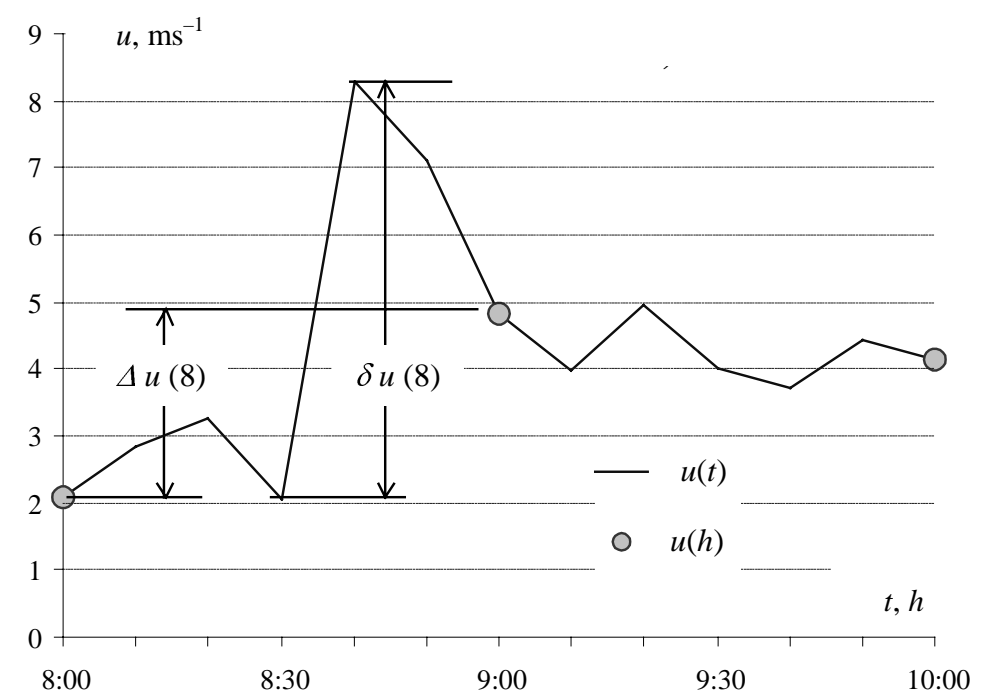

Fig. 10. Wind speed diagram at AVA on 14 June 2003 with the simple wind speed increment $\Delta u$ and selected wind speed increment, $\delta u>\Delta u$. 




Fig. 11. The simple $(\Delta u)$ and selected $(\delta u)$ wind speed increments, correlated at HRL at the height of $50 \mathrm{~m}$.

Therefore we define the selected wind speed increment as a maximum among shifted one-hour wind speed increments $\delta u>\Delta u$ within any selected hour, on the basis of a ten-minute step time scale ( $t=8: 00,8: 10,8: 20$, etc.) in Fig. 10. The selected wind speed increment is defined as

$$
\delta u(h)=\max \{|u(t+1)-u(t)|\}
$$

where $t$ is any discrete time instant in a ten-minute step time-scale, expressed in the one-hour time-scale. Averaging time of ten minutes is sufficient to control any WTG. Thus the selected wind speed increment really affects the grid.

A comparison of wind speed increments analysed by both methods for the HRL site is shown in Fig. 11. The correlation between conventional and selected wind speed increments is close to the functional relation $\delta u(h) \approx 1.7 \Delta u(h)$.

\section{CONCLUSIONS}

1. The characteristics of the wind speed increments in different conditions (site, height, average value of the wind speed, etc.) can be described by their frequency distribution function, which shows the probability of increments as a function of their values.

2. The frequency distribution function of wind speed increments is close to an exponential function.

3. Positive and negative wind speed increments have equal frequency distribution and can be analysed using their absolute values. 
4. The average values of wind speed increments do not depend on the average values of the wind speed.

5. Wind speed increments about $5 \mathrm{~m} \mathrm{~s}^{-1}$ have a maximum frequency at the height of $10 \mathrm{~m}$; at greater heights, this maximum is shifted towards a higher wind speed range.

6. Azimuth diagrams of small wind speed increments coincide with the conventional wind roses; analogous diagrams for large wind speed increments show a maximum for NW winds.

7. Values of wind speed increments depend on the data recording and processing technology. The impact of wind speed increments on the grid can be best evaluated by the selected wind increments, which are 1.5-2 times higher than increments defined conventionally (by hourly sampled data).

8. The dependence of wind speed increments on the height of the measurement is close to the step function; it is constant in the height range up to $20 \mathrm{~m}$ and is twice higher over $30 \mathrm{~m}$.

\section{ACKNOWLEDGEMENT}

The authors are grateful to the Estonian Science Foundation for support (grant No. 5051).

\section{REFERENCES}

1. Persaud, S., Fox, B. and Flynn, D. Impact of wind energy development on the operation of an isolated thermal power system. In Proc. European Wind Energy Conference. Copenhagen, 2001, 1207-1210.

2. Tomson, T. and Pirksaar, R. Investigation of the accuracy of prognosed wind energy. In Proc. Conference "Investigation and Application of Wind Energy" (Tiit, V., ed.). Estonian Agricultural University, Tartu, 2004, 29-36.

3. Durstewitz, M., Ensslin, C., Hoppe-Kilpper, M. and Rohrig, K. Electrical power from widelydispersed wind turbines. In Proc. European Wind Energy Conference. Dublin, 1997, 743746.

4. List of Ligths, Estonia. Estonian National Maritime Board, Tallinn, 1998.

5. Ensslin, C., Ernst, B., Hoppe-Kilper, M., Kleikauf, W. and Rohrig, K. Online monitoring of $1700 \mathrm{MW}$ wind capacity in a utility supply area. In Proc. European Wind Energy Conference. Nice, 1999, 444-447.

6. Tomson, T. and Nõva, A. Geographically dispersed wind turbines on the West-Estonian Coast. Agricult. Eng. Internat., 2001, 3 (http://cigr-ejournal.tamu.edu/articles.html).

7. Burton, T., Sharpe, D., Jenkins, N. and Bossany, E. Wind Energy (Handbook). J. Wiley, Chichester-Toronto, 2001. 


\title{
Tuule kiiruse frontide käitumine
}

\author{
Teolan Tomson ja Maire Hansen
}

On käsitletud tuule kiiruse muutude määramise metoodikat keskmise tuule kiiruse frontidel. On näidatud, et muutude iseloomustamiseks on sobiv nende eksponendile lähedase sagedusjaotuse kasutamine ning piisab muutude absoluutväärtuste analüüsist, sest positiivsete ja negatiivsete kiirusmuutude sagedusjaotus on sama. On uuritud tuule kiiruse muutude sõltuvust mõõtekõrgusest, tuule keskmisest kiirusest ja tuule suunast. On selgitatud, milliselt suunalt võib oodata suuremaid tuule kiiruse muute. Viimastel on praktiline tähendus energiasüsteemi töö korraldamisel, sest tuule kiiruse muudud määravad elektrisüsteemi talitlust mõjutavaid tuule võimsuse muute. 